\title{
Проблемы билингвизма \\ в системе школьного языкового образования Республики Тыва
}

\author{
Александр Л. Арефьев \\ Государственный институт русского языка им. А. С. Пушкина; Федеральный научно-исследовательский \\ социологический центр Российской академии наук, Российская Федерация, \\ Улданай М. Бахтикиреева, Владимир П. Синячкин \\ Российский университет дружбы народов, Российская Федерация
}

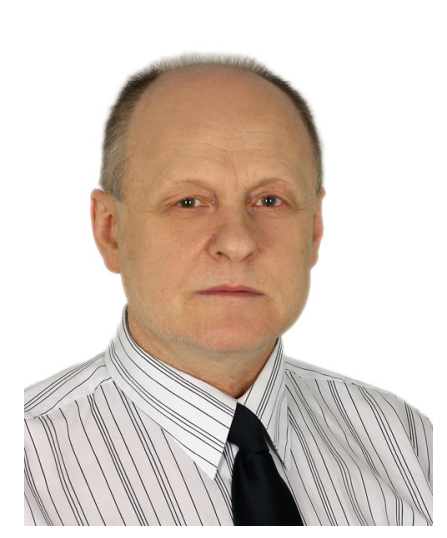

В статье анализируется современное состояние языкового образования как билингвального в системе школьного образования Тувы на фоне общероссийских процессов в этой сфере. В постсоветское время во всех регионах разворачивается неоднозначная ситуация в сфере языкового образования, связанная с особенностями демографического состояния сообществ и языковой политикой.

История преобразований в сфере лингвистического образования в Туве неразрывно связана с разновекторными изменениями национально-языковой политики России. Наряду с судьбоносными для тувинского народа позитивными изменениями неизбежными были и потери u, в частности - социокультурной и собственно лингвистической витальности тувинского языка в системе образования. По всей видимости, процесс этот закономерный, если рассматривать это соотношение в масштабах всех миноритарных языков не только в РФ, но и мире.

В отличие от других национальных республик России Тува долгое время была, в основном, моноязычной. Тем не менее за почти восемьдесят лет нахождения республики в составе российского государства здесь выросло по крайней мере два поколения тувинцев в новой социокультурной среде. Менявшаяся за этот исторический период языковая ситуация, непоследовательность в реализуемой билингвальной политике Тувы, отчасти связанная с непоследовательностью общей языковой политики в РФ, привели к формированию сложной ситуации коллективного билингвизма. По всей видимости, в системе образования Тувы наметилась тенденция разделения сфер использования тувинского и русского языков. Очевидно, что тувинский не выдерживает конкуренции с русским языком, как и любой другой язык РФ, тем более он фактически с 2018 г. перестал быть языком обучения. А кроме того, раннее введение доминирующего языка в двуязычных учреждениях дошкольного образования также уменьшает сферы использования языка, находящегося в подчиненной позиции.

Такая неравновесная билингвальная ситуация в перспективе может привести к потерям в процессе межпоколенной передачи тувинской культуры.

Ключевые слова: Тува; билингвизм; тувинско-русский билингвизм; тувинский язык; русский язык; языковая политика; школьная система образования; языковое образование; языковой сдвиг

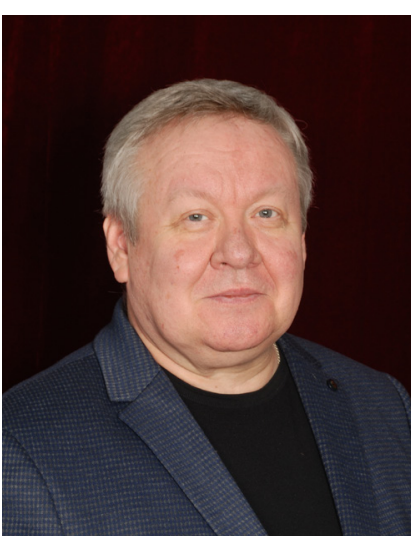

Для цитирования:

Арефьев А. Л., Бахтикиреева У. М., Синячкин В. П. Проблемы билингвизма в системе школьного языкового образования Республики Тыва // Новые исследования Тувы. 2021, № 1. С. 255-272. DOI: https://www.doi.org/10.25178/nit.2021.1.14

Арефьев Александр Леонардович - кандидат исторических наук, доцент, заместитель руководителя Центра исследований языковой политики и международного образования Государственного института русского языка им. А. С. Пушкина; старший научный сотрудник Федерального научно-исследовательского социологического центра Российской академии наук. Адрес: 117485, Россия, г. Москва, ул. Академика Волгина, д. 6. Тел.: +7 (495) 567-09-11. Эл. адрес: alexander.arefiev@gmail.com

- Бахтикиреева Улданай Максутовна - доктор филологических наук, профессор, профессор кафедры русского языка и межкультурной коммуникации факультета гуманитарных и социальных наук Российского университета дружбы народов. Адрес: 117198, Россия, г. Москва, ул. Миклухо-Маклая, д. 10А, каб. 283. Тел.: + 7 (495) 787-38-03

вн. 22-00. Эл. адрес: uldanai@mail.ru

Синячкин Владимир Павлович - доктор филологических наук, заведующий кафедрой и профессор кафедры русского языка и межкультурной коммуникации факультета гуманитарных и социальных наук Российского университета дружбы народов. Адрес: 117198, Россия, г. Москва, ул. Миклухо-Маклая, д. 10А, каб. 283. Тел.: + 7 (495) 787-38-03 вн. 22-00. Эл. адрес: word@list.ru 


\title{
Bilingualism in language education in secondary schools of the Republic of Tuva
}

\author{
Alexander L. Arefiev \\ A. S. Pushkin State Institute of Russian Language; Federal Research Center in Sociology, Russian Academy of Sciences, \\ Russian Federation, \\ Uldanai M. Bakhtikireeva, Vladimir P. Sinyachkin \\ Peoples' Friendship University of Russia, Russian Federation
}

\begin{abstract}
The article examines the contemporary situation in bilingual language education within the school system of the Republic of Tuva, comparing it with the same processes throughout Russia. In the Post-Soviet period, all regions saw the rise of an ambiguous state within language education due to specific demography and language policy.

The history of changes in language education in Tuva is inseparable from the opposing moves in Russia's national and linguistic policy. Alongside with the decisive and positive transformations in Tuvan culture, some losses were also inevitable, such as that of sociocultural and linguistic vitality of Tuvan language within the educational system. Seen in the context of the developments of all minority languages both in Russia and around the world, this process is most likely historically determined.

Unlike other 'ethnic republics' of Russia, Tuva has long remained mostly monolingual. Nevertheless, over 80 years of the history of Tuva within Russia means that at least two generations of Tuvans have grown up in the new sociocultural environment. Numerous changes in linguistic situation alongside with the absence of continuity in the policy of Tuvan bilingualism (largely due to similar lack of continuity in the language policy of Russia) gave rise to a complex phenomenon of collective bilingualism. Within the system of education in Tuva, the tendency is towards a redistribution of spheres of usage of Russian and Tuvan languages. Just as any other language in Russia, the latter obviously does not stand the competition against the former, especially given that since 2018 it has practically stopped functioning as a language of education. Moreover, the early introduction of Russian in bilingual pre-school education also narrows down the sphere of use of Tuvan as a language in the subordinate position.
\end{abstract}

This disbalance in the bilingual situation can potentially lead to disruptions in the intergenerational transfer of Tuvan culture.

Keywords: Tuva; bilingualism, Tuvan-Russian bilingualism; Tuvan language; Russian language; language policy; school system of education; language education; linguistic shift

\section{For citation:}

Arefiev A. L., Bakhtikireeva U. M. and Sinyachkin V. P. Bilingualism in language education in secondary schools of the Republic of Tuva. New Research of Tuva, 2021, no. 1, pp. 255-272. (In Russ.). DOI: https://www.doi.org/10.25178/ nit.2021.1.14

AREFIEV, Alexander Leonardovich, Candidate of History, Associate Professor, Deputy Director, Center for Studies of Language Policy and International Education, A. S. Pushkin State Institute of Russian Language; Senior Research Fellow, Federal Research Center in Sociology, Russian Academy of Sciences. Postal address: 6 Akademik Volgin St., 117485 Moscow, Russia. Tel.: +7 (495) 56709-11. Email: alexander.arefiev@gmail.com

ORCID ID: 0000-0002-6368-3713 BAKHTIKIREEVA, Uldanai Maksutovna, Doctor of Philology, Professor, Department of Russian and Intercultural Communication, Faculty of the Humanities and Social Sciences, Peoples' Friendship University of Russia. Postal address: Off. 283, 10a Miklouho-Maclay St., 117198 Moscow, Russia. Tel.: + 7 (495) 787-38-03 int. 22-00. Email: uldanai@mail.ru

ORCID ID: 0000-0001-5088-7568

SINYACHKIN, Vladimir Pavlovich, Doctor of Philology, Associate Professor and Chair, Department of Russian and Intercultural Communication, Faculty of the Humanities and Social Sciences, Peoples' Friendship University of Russia. Postal address: Off. 283, 10a Miklouho-Maclay St., 117198 Moscow, Russia. Tel.: + 7 (495) 787-38-03 int. 22-00. Email: word@list.ru 


\section{Введение}

Самая комфортная языковая ситуация, которая бы отвечала запросу любого многонационального государства, включая Российскую Федерацию - это функционирование одного языка для всех народов в нем проживающих. Однако, как показывает опыт разных стран, в т. ч. высоко технологически развитых, достижение такого комфорта - сложная проблема. Сложности не отменяют планов государств по формированию единой политической нации, «которое будучи многонародным», в то же время могло бы представлять «национальное единство» (Марусенко, 2015: 280). Эта идея национального единства повсеместно реализовывается в рамках государственной языковой политики (не только эксплицитной, но и имплицитной), прежде всего, в системе образования. В силу изменений ценностных смыслов государственной идеологии в России за последний век лингвистическое образование народов двигалось в русле общей национально-языковой политики российского государства.

В данной статье мы проанализируем современное состояние языкового образования как билингвального в системе школьного образования Тувы на фоне общероссийских процессов в этой сфере. Хотя тувинская система школьного образования на протяжении XX столетия развивается в русле общей государственной политики России, она имела свои особенности вплоть до вступления в состав СССР в 1944 г. Тем не менее с конца 1950-х годов в Туве стал наблюдаться схожий процесс сужения сфер использования национальных языков в образовательной системе, как и во всех миноритарных 1 сообществах. Это время характеризуется языковой политикой гомогенизации (русификации) единой культурно-исторической общности - советский народ (Беликов, Крысин, 2001). Отнюдь не случайно ученые характеризуют его началом периода языкового сдвига в ущерб тувинскому языку (Цыбенова, 2018 и др.).

Относительно других регионов в Туве функционирование языка коренного этноса более благополучное в Российской Федерации, благодаря увеличению доли тувинцев в национальном составе населения республики (как следствие миграционных процессов последних двадцати лет) и их компактным проживанием на одной территории (Цыбенова, 2019). Однако, это лишь один из аспектов языковой ситуации. Отток русскоязычных специалистов, начавшийся в 1990-е гг., в том числе из системы образования, привел к тому, что в сельских районах даже русский язык и литература преимущественно преподавались на тувинском языке. Но с 2018 г. система школьного образования Тувы официально перешла на русскоязычное обучение. Все эти обстоятельства определили неоднозначную ситуацию с билингвальным образованием в республике, которая требует внимательного изучения и постоянного мониторинга в силу принятия новой государственной программы.

Источниковой базой исследования выступили труды исследователей в области социолингвистики, в том числе и тувинской, теории языковых контактов и билингвизма, а также статистические данные, полученные нами из Министерства образования и науки Республики Тыва в 2020 г.

\section{Исторические предпосылки}

Система народного просвещения с вхождением Тувы в состав СССР в 1944 г., также усиленно, как и остальные сферы общественной жизни, стала строиться по советскому образцу и базировалась на принципах всеобщего обучения (Товуу, Кара-Сал, Санчаа, 2020: 50). В учебный процесс внедрялись советские учебные программы и учебники, которые также переводились с русского на тувинский; выходили учебники на тувинском языке. С 1948/1949 учебного года русский язык в Туве начинает преподаваться в качестве предмета, затем он становится и языком обучения. С открытием Учительского института осуществляется подготовка местных педагогических кадров (Сат, 1973: 22-23).

Как пишут В. И. Беликов и Л. П. Крысин,

«в СССР не проводился намеренный курс на русификацию, скорее можно говорить о всемерном продвижении и расширении функциональных возможностей общепонятного для всего государства языка. Судьбами остальных языков центр не интересовался, и уровень их поддержки зависел от республиканских и местных властей. Достижение всеобщего национально-русского двуязычия, ставшее стандартным лозунгом с 1970-х годов, имело целью не последующую русификацию, а по возможности быструю идеологическую унификацию в рамках провозглашенной тогда новой исторической общности - советских людей» (Беликов, Крысин, 2001: 289-290).

${ }^{1}$ «Миноритарный» в данном случае синонимично термину «малочисленный», однако смещает фокус внимания с количественной характеристики на качественную. 
Идеология унификации советского общества привела к сокращению обучения на миноритарных языках. Если в начале 1960-х обучение в РСФСР велось на 47 языках, то к началу 1970-х - на 30. Среднее образование велось на татарском и башкирском. На якутском получали неполное среднее образование, на бурятском - шестилетнее, на тувинском - семилетнее образование (там же: 287). В 1982 г. число языков, на которых велось обучение, сократилось до 17. Однако, как отмечают В. И. Беликов и Л. П. Крысин, наиболее «стойкие» языки сохраняли и даже усиливали свои позиции: на тувинском и якутском языках дети получали восьмилетнее образование, а на татарском и башкирском - среднее образование (там же: 289).

Современные исследователи, приводя данные переписи 1989 г. сообщают, что родным русский язык назвал 1,38\% тувинцев, а не говорят по-русски свободно - 39,46\% (Беликов, Крысин, 2001: 292). Тем не менее, еще в начале 1970-х годов Ш. Ч. Сат писал, что в Туве уже сформировался «тувинско-русский билингвизм смешанного типа» (Сат, 1973: 25). В Туве действительно распространился асимметричный билингвизм или семилингвизм (полуязычие), что означает появление людей, усваивающих оба языка, но не в полной мере. Один язык они могут использовать на уровне разговорно-бытового и / или языка художественной литературы, на другом - разговорно-бытовой и / или язык деловой и т. п.

Различия соотношений языков проявлялись в разных типах поселения: русский язык развивался преимущественно в городах, родной - на селе (Очур, 2015: 94). Слабый уровень преподавания русского языка и литературы в сельских школах, а также отсутствие там языковой среды, приводили к тому, что до половины абитуриентов, поступавших в 1980-х гг. на внеконкурсные места в вузы, получали неудовлетворительные оценки по русскому языку (там же).

Тем не менее, к моменту распада СССР в Туве основная часть школ (85\%) была смешанной. Н. М. Очур приводит данные на 1991 г., когда тувинский язык как учебный предмет изучали 64,0\% всех школьников республики, а обучались на родном языке 50,2\% (там же).

Выгодность, социальный престиж русского языка постепенно меняли языковую лояльность тувинцев (Цыбенова, 2013), но прежде всего в городах. В республике, особенно в его урбанизированных центрах, распространились и тувинцы, которые стали больше использовать русский язык в форме неполного транслингвизма ${ }^{1}$, а также полностью перешедшие на русский язык (Очур, 2015: 93).

\section{Тувинский язык в системе образования в постсоветский период}

Распад СССР и появление постсоветских государств обусловили расширение языковых прав народов. В 1990-2000-х годах во многих регионах были приняты законодательные нормы, гарантирующие право на получения образования на родных языках и изучение их в учебных заведениях.

С принятием в 1990 г. «Закона о языках в Тувинской АССР» русский язык в республике получил статус языка межнационального общения ${ }^{2}$ и в школах Тувы началось введение модели билингвального обучения. Последовавшие после 1991 г. процессы национально-культурного и языкового возрождения, по мнению ученых, обозначили в Туве две тенденции. С одной стороны, возрос интерес к культуре и языку титульной национальности со стороны русскоязычного населения. Так, в рамках проекта «Социокультурные факторы экономического развития Тувы» (1991-1994) 70\% опрошенных русских, независимо от занимаемой ими социально-профессиональной ниши, ответили, что проявляют интерес к культуре, языку тувинцев. Опрос молодежи этносоциологами в 1997 г. показал, что более половины русских были согласны с введением тувинского языка во все школы Тувы, включая русские, в качестве обязательного предмета $(51,2 \%)$. Несогласные составляли менее трети $-28,8 \%$ (Анайбан, Губогло, Козлов, 1999: 97-98). Практически все опрошенные учителя школ в ходе социологического исследования Г. М. Селиверстовой 1993 г. высказывались за обучение на тувинском языке с 1 по 11 классы, однако в ходе аналогичного исследования в 1997-1998 гг. подавляющая часть опрошенных отдала предпочтение двуязычному школьному образованию (47,5\%) или полностью русскоязычному $(36,3 \%)^{3}$.

\footnotetext{
${ }^{1}$ Транслингвизм - смена языка или периодического возвращения в соответствующих ситуациях к этническому языку.

${ }^{2}$ Тувинская АССР. Закон от 14 декабря 1990 года № 96. О языках в Тувинской АССР [Электронный ресурс] // Pravo. Tech. URL: http://docs.pravo.ru/document/view/14459985 (дата обращения: 21.01.2021).

${ }^{3}$ Селиверстова Г. М. Родной язык не нужен? Как решить проблемы двуязычия [Электронный ресурс] // Учительская газета. 2008, 8 января. URL: http://www.demoscope.ru/weekly/2008/0317/gazeta025.php (дата обращения: 21.01.2021).
} 
С другой стороны, замечают исследователи, возрождение ценностей тувинской культуры приводило часть населения к неприятию инонационального. Например, имевшее место в эти годы недостаточное развитие русского языка со стороны соответствующих инстанций республики, отразилось на уровне владения им как школьниками, так и студентами вузов. Так, из 400 опрошенных во второй половине 1990-х гг. респондентов-тувинцев, обучавшихся в разных средних специальных заведениях, по их самооценке, свободно владели русским языком $59,8 \%$, с затруднениями $-36,3 \%$, с большим трудом $-3,5 \%$ (там же: 98).

Для адекватного владения двумя языками важна языковая практика. Уменьшение количества русских учеников, несомненно, повлияло на уровень владения русским языком сверстниками. «Например, из всего числа выбывших за пределы республики в 1997 г. доля русских составила 64\%» (там же: 36). Здесь не будет преувеличением замечание о том, что одной из причин оттока русскоязычных людей из национальных республик является нежелание изучать местные языки. И дело здесь не столько в росте этнического сознания, характерного периоду начала 1990-х, сколько в затратности для человеческого организма дополнительных умственных усилий, требующихся для овладения новыми знаниями, и отсутствии мотивации и выгод.

Статья 5 Закона Республики Тыва «Об образовании» 1995 г. ${ }^{1}$ закрепила право получения дошкольного воспитания и общеобразовательной подготовки на государственных языках Тувы и России. Преемственность и непрерывность воспитания и обучения на родном языке провозглашались как основа национально-культурного развития личности. Выпускники общеобразовательных школ могли при поступлении в учебные заведения республики сдавать экзамены на обоих языках.

Как писали в конце прошлого века 3. В. Анайбан и ее коллеги, по данным переписи населения 1989 г. считали родным языком - тувинский 99,2\% тувинцев (показав тем самым один из самых высоких показателей сохранения языков своей национальности в качестве родного). Но при этом более половины $(58,3 \%)$ владели русским языком. И главным фактором развития тувинско-русского билингвизма авторы назвали систему школьного образования, поскольку $57,2 \%$ опрошенных указали на школу как на место, где именно они овладели русским языком. Иная ситуация сложилась с русско-тувинским двуязычием (знание русскими тувинского языка). Если несколько десятилетий назад владение языком коренных жителей для русских было довольно обычным явлением, то к концу 1990-х годов тувинский знали лишь 0,6\% русскоязычного населения Тувы (Анайбан, Губогло, Козлов, 1999: 97).

В 2015 г. Н. М. Очур подчеркнула, что в настоящее время в республике есть понимание объективной необходимости в знании русского языка, а вот инициативы по поводу обязательного знания языка титульной национальности отдельными категориями населения пока остаются пожеланиями. Но в целом идет работа по сбалансированному развитию русско-тувинского и тувинско-русского билингвизма в республике (Очур, 2015: 96). Посмотрим на современное состояние дел в этой сфере.

\section{Двуязычие на современном этапе}

Школьное образование на русском языке, по-прежнему, считается более качественным и перспективным с социально-профессиональной точки зрения, в связи с чем все больше родителей Тувы ориентируются на русскую школу. Факт престижности русского языка очевиден: «Тувинцы владеют своим родным тувинским языком достаточно хорошо, но социального престижа в нем не видят» (Серээдар, 2018: 14).

Подобная ситуация в Российской Федерации происходит практически со всеми миноритарными языками. К примеру, из 34-х тюркских языков РФ, в школьном образовании в той или иной мере сегодня используется лишь половина. Не участвуют в учебном процессе языки гагаузов, каракалпаков, киргизов, нагайбаков, туркмен, узбеков, уйгур, теленгитов, сойотов, кумандинцев, караимов, челканцев, чулымцев. Крайне недостаточно представлен казахский как средство обучения, хотя в РФ проживает около 1 миллиона этнических казахов. Его учили как предмет «Родной язык» немногим более 1 тыс. школьников из казахских семей. В Астраханской области, где проживает самая большая

${ }^{1}$ Закон Республики Тыва «Об образовании» [Электронный ресурс] // Гарант. URL: http://base.garant.ru/28700034 /8b7b3c1c76e91f88d33c08b3736aа67a/ (дата обращения: 21.01.2021). 


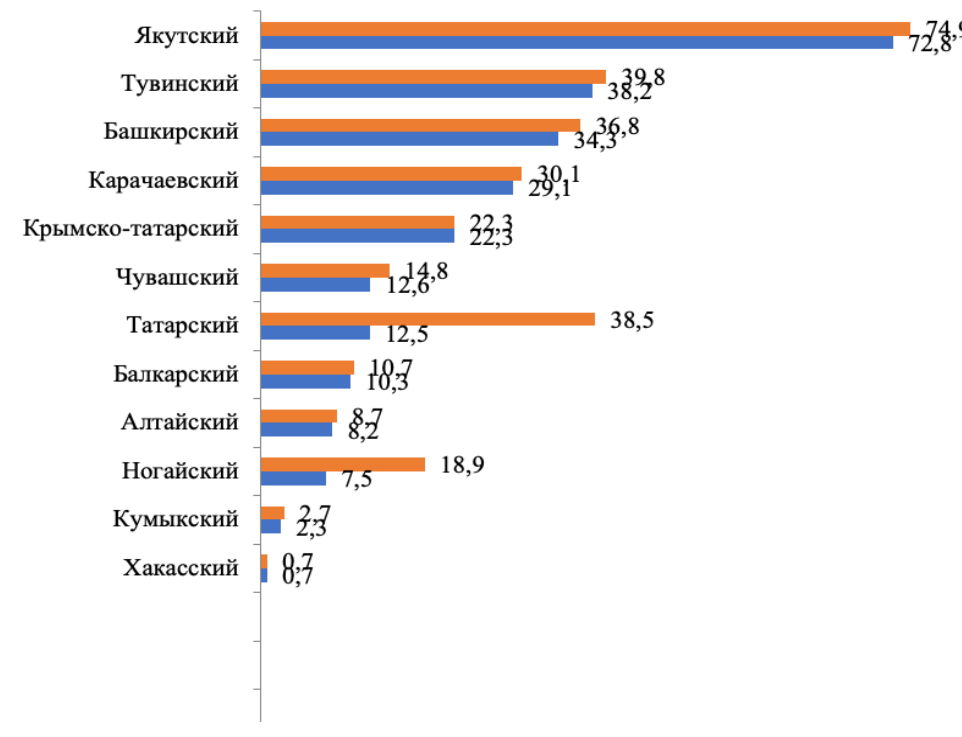

Диаграмма 1. Доля молодежи школьного возраста (7-17 лет) соответствующей тюркской национальности, обучавшаяся на родном тюркском языке в 2016/2017 году по РФ в целом и по национальному субъекту РФ, в \%.

Diagram 1. The share of school-age youth (7-17) of the respective Turkic ethnicity who received education in their native language in 2016/2017 academic year (percentage in Russia and the ethnic region).

Прим.: Составлено и рассчитано по данным Всероссийской переписи населения 2010 г., данным текущего учета населения и отчетным данным органов управления образования национальных субъектов РФ (национальный республик, краев и областей) за 2016/2017 уч. г.

диаспора и в Алтайском крае, где этот язык имеет право функционирования в официальных сферах общения в местах компактного проживания его носителей (которых более 12 тыс. человек) ${ }^{2}$.

В законе «Об образовании в Российской Федерации» (2012 г.) оговаривалось, что граждане РФ имеют право на получение школьного образования на родном языке, а также его изучение в пределах возможностей, предоставляемых системой образования (статья $14^{3}$ ). Здесь же отмечалось, что «Реализация указанных прав обеспечивается созданием необходимого числа соответствующих образовательных организаций, классов, групп, а также условий для их функционирования»4. Однако указание на это обеспечение применительно, в том числе к тюркским языкам, выполняется далеко не в полной мере (Арефьев, 2018: 67). Для сравнения представим диаграмму, показывающую процентное соотношение 12 тюркских языков, функционировавших в качестве средства обучения в 2017 г. (см. диаграмму 1), а в 2019 г. их количество сократилось до 10.

В упомянутом законе об образовании подчеркивается приоритетное положение государственного - русского языка, на котором в первую очередь должна осуществляться образовательная деятельность. В Туве по причине проблем с использованием русского как средства обучения, невысоким качеством преподавания как учебного предмета и слабым владением значительной частью сельского населения, в 2013 г. была принята государственная программа «Развитие русского языка на 2014-2018 годы», введена должность главного государственного инспектора по русскому языку в ранге заместителя министра образования, 2014 год в республике был объявлен Годом русского языка, а с 2018 г. министерством образования и науки РТ было предписано преподавание во всех средних школах вести на русском языке. Ранее (в 2003 г.) был принят новый Закон «О языках в Республике Тыва», восстановивший государственный статус русского языка 5 . Предпринимались меры и по стимулированию работы учителей русского языка и литературы в школах сельских поселений (Боргоякова, Биткеева, 2020: 55).

${ }^{1}$ Образование в России - 2017. Статистический бюллетень. М.: Московский технологический университет, 2017. С. $87-89,107-110$.

2 Лаханулы Н. «Во всей России - одна казахская школа» [Электронный ресурс] // Радио Азаттык. 2014,12 января. URL: https://rus.azattyq.org/a/kazakhi-diaspora-V-rossii-interview/25227274.html (дата обращения: 21.01.2021); В Астраханской области проживает самая большая казахская диаспора в РФ [Электронный ресурс] // 24Хабар. 2020, 25 декабря. URL: https://24.kz/ru/news/culture/item/444710-v-astrakhanskoj-oblasti-samaya-bolshayakazakhskaya-diaspora-V-rf (дата обращения: 21.01.2021).

${ }^{3}$ Статья 14. Федеральный закон от 29.12.2012 № 273-Ф3 (ред. от 08.12.2020) «Об образовании в Российской Федерации» (с изм. и доп., вступ. в силу с 01.01.2021) [Электронный ресурс] // КонсультантПлюс. URL: http:// www.consultant.ru/document/cons_doc_LAW_140174/bf7fadb3532c712ccd28cc2599243fb8018ed869/ (дата обращения: 21.01.2021).

${ }^{4}$ Там же.

${ }^{5}$ Статья 8. Изучение и преподавание языков в Республике Тыва / Закон Республики Тыва от 31 декабря 2003 г. № 462 BX-I «О языках в Республике Тыва» (с изменениями и дополнениями) [Электронный ресурс] // Гарант. URL: http://base.garant.ru/28701589/31de5683116b8d79b08fa2d768e33df6/ (дата обращения: 21.01.2021). 
Вместе с этим, тувинские ученые, в том числе М. В. Бавуу-Сюрюн, привлекали внимание к проблемам тувинского языка, который «вступил в критический этап своего существования, появились признаки реальной ассимиляции», прежде всего, в системе образования - одной из сфер интенсивного функционирования тувинского языка (Бавуу-Сюрюн, 2010: 62). Крайне остро была обозначена проблема преподавания тувинской литературы в школе, которую невозможно решать без «соответствующей литературной критики и анализа абсолютного большинства произведений тувинской литературы, предложенных в качестве программных» (там же: 65). В связи с комплексом этих и других проблем в 2017 г. была принята Государственная программа Республики Тыва «Развитие тувинского языка на 2017-2020 годы» ${ }^{1}$. Одним из важных направлений программы являлся пересмотр обучения тувинскому языку и в детских садах. Согласно мониторингу в рамках проекта «Тувинский язык - детям» в 2019 г. среди 197 дошкольных образовательных учреждений республики обнаружился значительный процент тувинцев-дошкольников, не владевших родным языком (в Кызыле - 21,2\% или 1629 воспитанников из 7667). В детских садах кожуунов этот показатель значительно ниже - не владели языком около 7\% тувинцев (или 1093 воспитанника из 15264). При этом доля семей, желавших обучать детей на тувинском языке, составила в г. Кызыле 55\% (3991 из 7128 семей), в кожуунах - 69\% (9632 из 13792$)^{2}$.

Отмечая позитивные стороны языковой политики начала XXI в., тувинские ученые положительно оценили изменения содержательных целей в школьном образовании, развитие вариативности, в т. ч. математического образования, усиление экспериментальной деятельности школ (Товуу, Кара-Сал, Санчаa, 2020: 53, 56). Однако, несбалансированная реализация двух государственных программ по развитию языков, прежде всего, влияла на лингвистическую витальность тувинского языка. Несмотря на высокие показатели владения тувинцами, «во многом права тувинского языка декларативны, а функции и сфера применения стремительно сужаются», что служит основой для языкового сдвига, асимметричного билингвизма (Донгак, 2020: 67, 68). В учебных заведениях тувинский язык все больше стал рассматриваться как второстепенный предмет.

\section{Изучение тувинского языка в системе школьного образования}

Принятие поправок в федеральный закон «Об образовании» 2012 г. заметно сказалось на соотношение обучения на тувинском и русском языках и, в целом - на билингвальном образовании в РТ. Если на рубеже 1990-2000-х более половины школьников обучались на тувинском языке - преимущественно в младших классах, то в 2016/2017 уч. году заметно выросло число учеников на тувинском в средних классах. Однако с 2017/2018 уч. года доля обучавшихся на тувинском стала сокращаться.

С 2019/2020 учебного года школьное образование в Туве стало полностью русскоязычным и динамика по обучению на тувинском языке резко пошла на спад (см. диаграмму 2 и таблицу 1).

Обучение на тувинском осуществлялось почти во всех школах, преимущественно билингвальных (полностью русскоязычными были менее 10\% общеобразовательных организаций, в основном в столице Кызыле и в г. Ак-Довураке).

Таблица 1. Численность школьников, обучавшихся на тувинском языке в школах городских и сельских поселений РТ в 2011/2012-2018/2019 учебных годах.

Table 1. The number of school students who received education in Tuvan language in schools of urban and rural settlements of the Republic of Tuva, 2011/2012 - 2018/2019.

\begin{tabular}{|c|c|c|c|c|c|c|c|}
\hline \multirow{2}{*}{$\begin{array}{c}\text { Учебные } \\
\text { годы }\end{array}$} & \multirow[b]{2}{*}{ Поселения } & \multirow{2}{*}{$\begin{array}{c}\text { Кол-во } \\
\text { школ }\end{array}$} & \multicolumn{3}{|c|}{ Классы } & \multirow{2}{*}{$\begin{array}{c}\text { Число обучавшихся в } \\
\text { городских и сельских } \\
\text { школах, чел. }\end{array}$} & \multirow{2}{*}{$\begin{array}{c}\text { Всего } \\
\text { обучалось, } \\
\text { чел. }\end{array}$} \\
\hline & & & $1-4$ & $5-9$ & $\begin{array}{c}10-11 \\
(12)\end{array}$ & & \\
\hline \multirow{2}{*}{$2011 / 2012$} & Городские & 27 & 6844 & 601 & - & 7445 & \multirow{2}{*}{18235} \\
\hline & Сельские & 122 & 9424 & 1266 & - & 10790 & \\
\hline
\end{tabular}

${ }^{1}$ Государственная программа Республики Тыва «Развитие тувинского языка на 2017-2020 годы». Утверждена постановлением Правительства Республики Тыва от 7 апреля 2017 г.№ 152 [Электронный ресурс]//Электронный фонд правовой и нормативно-технической документации. URL: http://docs.cntd.ru/document/446197328 (дата обращения: 21.01.2021).

${ }^{2}$ В рамках проекта «Тувинский язык детям» проведен зональный семинар по развитию тувинского языка в дошкольных учреждениях Республики Тыва [Электронный ресурс] // Институт развития национальной школы Республики Тыва. 2019, 17 сентября. URL: http://irnsh.ru/2019/09/17/v-respublike-tyva-v-doshkolnykhobrazo/ (дата обращения: 21.01.2021). 


\begin{tabular}{|c|c|c|c|c|c|c|c|}
\hline \multirow{2}{*}{$2012 / 2013$} & Городские & 27 & 7163 & - & - & 7163 & \multirow{2}{*}{17748} \\
\hline & Сельские & 122 & 9633 & 952 & - & 10585 & \\
\hline \multirow{2}{*}{$2013 / 2014$} & Городские & 26 & 7357 & 247 & 64 & 7668 & \multirow{2}{*}{18282} \\
\hline & Сельские & 121 & 9503 & 1111 & - & 10614 & \\
\hline \multirow{2}{*}{$2014 / 2015$} & Городские & 26 & 7990 & 240 & 67 & 8297 & \multirow{2}{*}{18910} \\
\hline & Сельские & 121 & 9809 & 804 & - & 10613 & \\
\hline \multirow{2}{*}{$2015 / 2016$} & Городские & 27 & 8731 & - & - & 8754 & \multirow{2}{*}{19776} \\
\hline & Сельские & 121 & 10318 & 704 & - & 11022 & \\
\hline $2016 / 2017$ & $\begin{array}{l}\text { Городские } \\
\text { +сельские }\end{array}$ & 149 & 17507 & 4630 & 696 & 22587 & 22587 \\
\hline $2017 / 2018$ & $\begin{array}{l}\text { Городские } \\
\text { +сельские }\end{array}$ & 10 & 2116 & 314 & 39 & 2320 & 2320 \\
\hline $2018 / 2019$ & $\begin{array}{l}\text { Городские } \\
\text { +сельские }\end{array}$ & 3 & 337 & - & 20 & 357 & 357 \\
\hline
\end{tabular}

Прим.: Составлено по данным на начало каждого учебного года.

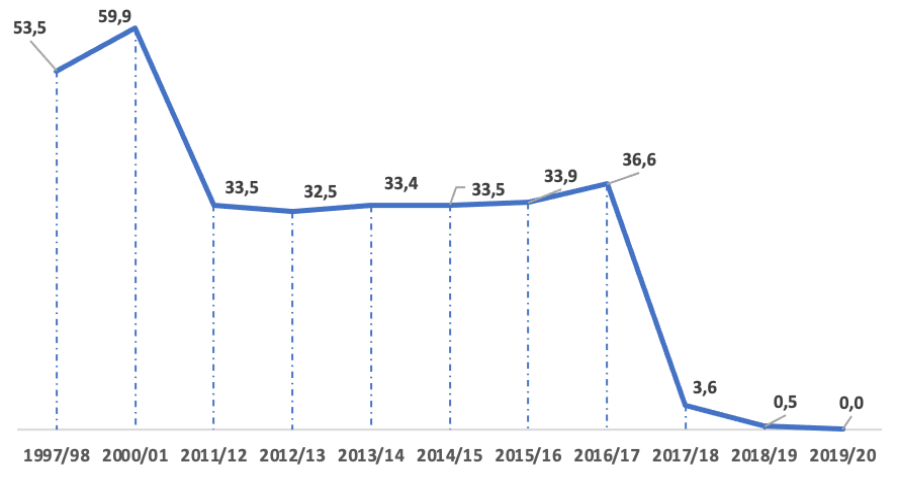

Диаграмма 2. Доля школьников РТ, обучавшихся на тувинском языке в 1997/1998-2018/2019 уч. годах, в \%.

Diagram 2. The percentage of school students who received education in Tuvan language in the Republic of Tuva, 1997/1998-2018/2019.

Прим.: Составлено по данным на начало каждого учебного года ${ }^{1}$
В государственной программе РТ «Развитие государственных языков Республики Тыва на 2021-2024 годы» (принятой постановлением Правительства РТ от 8 декабря 2020 г. № 610) ${ }^{2}$. Приоритетной целью было «Развитие русского языка как инструмента формирования и укрепления единого образовательного пространства Российской Федерации и Республики Тыва, которое достигается путем создания условий, соответствующих основным современным требованиям (в соответствии с федеральными государственными образовательными стандартами), обучающимся в государственных и муниципальных общеобразовательных организациях» ${ }^{3}$. Здесь же подчеркивалась необходимость создания «условий для сохранения, развития тувинского языка как государственного языка Республики Тыва» ${ }^{4}$

${ }^{1}$ Источники: Образование в России - 2008. Статистический бюллетень. М.: МГУПИ, 2009. 436 с.; Образование в России - 2012. Статистический бюллетень. М.: МГУПИ, 2012. 584 с.; Образование в России - 2013. Статистический бюллетень. М.: МГУПИ, 2013. 584 с.; Образование в России - 2014. Статистический бюллетень. М.: МГУПИ, 2014. 593 с.; Образование в России - 2015. Статистический бюллетень. М.: МИРЭА, 2015.630 с.; Образование в России - 2016. Статистический бюллетень. М.: МГУПИ, 2016. 630 с.; Образование в России 2017. Статистический бюллетень. М.: Московский технологический университет, 2017. 444 с.; Образование в России - 2018. Статистический бюллетень. М.: МИРЭА - Российский технологический университет, 2018. 422 с.; Образование в России - 2019. Статистический бюллетень. М.: МИРЭА - Российский технологический университет, 2019. 478 с.

${ }^{2}$ Об утверждении новой Государственной Программы Республики Тыва «Развитие государственных языков Республики Тыва на 2021-2024 годы» [Электронный ресурс] // Электронный фонд правовой и нормативнотехнической документации. URL: http://docs.cntd.ru/document/571035348 (дата обращения: 21.01.2021).

${ }^{3}$ Цит. по: там же.

${ }^{4}$ Там же. 
Ситуация с изучением тувинского языка как родного в национальной системе образования к настоящему времени выглядит более благоприятной. В 2018/2019 учебном году его учили 68,4\% школьников, что превзошло рекордный показатель 1990/1991 уч. года (64,0\%) (см. диаграмму 3). Правда, прирост доли изучающих тувинский как учебный предмет произошел за счет школьников, которые ранее обучались на тувинском языке и данный процесс начался с 2016/2017 учебного года.

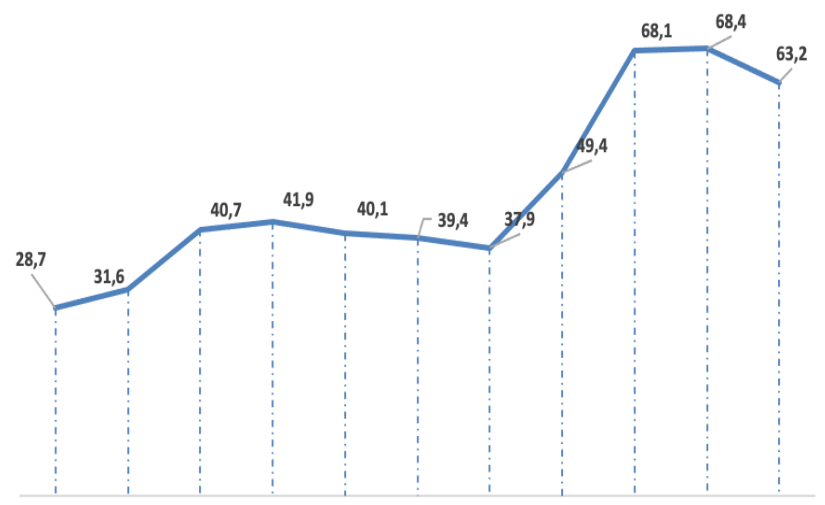

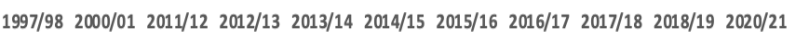

Диаграмма 3. Доля школьников РТ, изучавших тувинский язык как родной в 1997/1998-2020/2021 уч. годах, в \%.

Diagram 3. The percentage of students in the Republic of Tuva who studied Tuvan as their native language, 1997/1998-2020/2021.

Прим.: Составлено на начало каждого учебного года (за 1997/98-2018/19 учебные года) ${ }^{1}$ и данным Института развития национальной школы Республики Тыва - за 2020/21 учебный год.

Большинство изучающих тувинский как родной язык - обучающиеся в школах сельских (районных) поселений кожуунов (см. таблицу 2).

Таблица 2. Численность школьников, изучавших тувинский язык как родной в школах городских и сельских поселений РТ в 2011/2012-2020/2021 уч. годах

Table 2. The number of school students who studied Tuvan as their native language in schools of urban and rural settlements of the Republic of Tuva, 2011/2012-2020/2021.

\begin{tabular}{|c|c|c|c|c|c|c|c|}
\hline \multirow[b]{2}{*}{ Учебные годы } & \multirow[b]{2}{*}{ Поселения } & \multirow{2}{*}{$\begin{array}{l}\text { Кол-во } \\
\text { школ }\end{array}$} & \multicolumn{3}{|c|}{ Классы } & \multirow{2}{*}{$\begin{array}{c}\text { Число обучавшихся в } \\
\text { городских и сельских } \\
\text { школах } \\
\end{array}$} & \multirow{2}{*}{$\begin{array}{c}\text { Всего } \\
\text { обучалось }\end{array}$} \\
\hline & & & $1-4$ & $5-9$ & $\begin{array}{c}10-11 \\
(12)\end{array}$ & & \\
\hline \multirow{2}{*}{$2011 / 2012$} & Городские & 31 & - & 6855 & 1842 & 8697 & \multirow{2}{*}{22154} \\
\hline & Сельские & 117 & - & 9279 & 4178 & 13457 & \\
\hline \multirow{2}{*}{$2012 / 2013$} & Городские & 31 & 136 & 7059 & 1756 & 8951 & \multirow{2}{*}{22297} \\
\hline & Сельские & 118 & 0 & 9564 & 3932 & 13946 & \\
\hline \multirow{2}{*}{$2013 / 2014$} & Городские & 30 & 213 & 7123 & 1674 & 9010 & \multirow{2}{*}{21932} \\
\hline & Сельские & 117 & - & 9350 & 3572 & 12922 & \\
\hline \multirow{2}{*}{$2014 / 2015$} & Городские & 30 & - & 7625 & 67 & 1491 & \multirow{2}{*}{22221} \\
\hline & Сельские & 116 & - & 9781 & 3324 & 13105 & \\
\hline \multirow{2}{*}{$2015 / 2016$} & Городские & 30 & - & 8122 & 1180 & 9302 & \multirow{2}{*}{22109} \\
\hline & Сельские & 116 & - & 10005 & 2802 & 12807 & \\
\hline $2016 / 2017$ & $\begin{array}{l}\text { Городские } \\
\text { +сельские }\end{array}$ & $\begin{array}{c}\text { нет } \\
\text { данных }\end{array}$ & 12676 & 14850 & 3058 & 30451 & 30451 \\
\hline $2017 / 2018$ & $\begin{array}{l}\text { Городские } \\
\text { +сельские }\end{array}$ & $\begin{array}{c}\text { нет } \\
\text { данных }\end{array}$ & 21610 & 19452 & 3279 & 44028 & 44028 \\
\hline $2018 / 2019$ & $\begin{array}{l}\text { Городские } \\
\text { +сельские }\end{array}$ & $\begin{array}{c}\text { нет } \\
\text { данных }\end{array}$ & 21664 & 21131 & 3795 & 45980 & 45980 \\
\hline $2020 / 2021$ & $\begin{array}{l}\text { Городские } \\
\text { +сельские }\end{array}$ & $\begin{array}{c}\text { нет } \\
\text { данных }\end{array}$ & 20167 & 22382 & 3229 & 45778 & 45778 \\
\hline
\end{tabular}

Прим.: Составлено на начало каждого учебного года (за 1997/98-2018/19 учебные года) и данным Института развития национальной школы Республики Тыва - за 2020/21 учебный год.

${ }^{1}$ Источники: Образование в России - 2008. Статистический бюллетень. М.: МГУПИ, 2009. 436 с.; Образование в России - 2012. Статистический бюллетень. М.: МГУПИ, 2012. 584 с.; Образование в России - 2013. Статистический бюллетень. М.: МГУПИ, 2013. 584 с.; Образование в России - 2014. Статистический бюллетень. М.: МГУПИ, 2014. 593 с.; Образование в России - 2015. Статистический бюллетень. М.: МИРЭА, 2015. 630 с.; Образование в России - 2016. Статистический бюллетень. М.: МГУПИ, 2016. 630 с.; Образование в России - 2017. Статистический бюллетень. М.: Московский технологический университет, 2017. 444 с.; Образование в России - 2018. Статистический бюллетень. М.: МИРЭА - Российский технологический университет, 2018. 422 с.; Образование в России - 2019. Статистический бюллетень. М.: МИРЭА - Российский технологический университет, 2019. 478 с. 


\title{
По республике
}

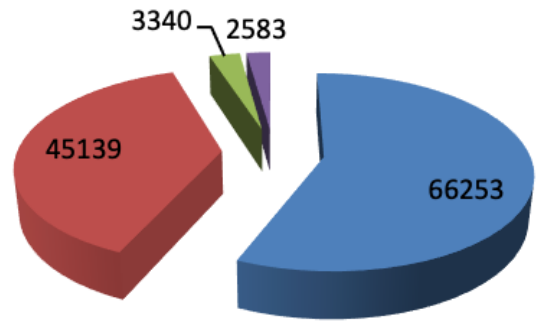

\author{
всего учащихся \\ изучают тув язык \\ всего классов \\ изучают тув язык
}

Диаграмма 4. Изучение тувинского языка и тувинской литературы в общеобразовательных организациях РТ в 2018/2019 уч. году. Diagram 4. Studying Tuvan and Tuvan literature in comprehensive schools in the Republic of Tuva in academic year $2018 / 2019$.

Прим.: По данным Института развития национальной школы РТ на конец 2018/2019 уч. года (без учета обучающихся с ограниченными возможностями здоровья).

Последние группы школьников, закончивших обучение в 2019/2020 уч. году на тувинском языке, являлись учащимися 4-х классов трех школ: МБОУ СОШ № 2 села Мугур-Аксы Монгун-Тайгинского кожууна (31 чел.), МБОУ Моген-Буренская СОШ Монгун-Тайгинского кожууна (29 чел.) и МБОУ СОШ № 1 села Мугур-Аксы Монгун-Тайгинского кожууна (65 чел.).

Более наглядно ситуация с изучением тувинского языка как родного в общеобразовательных организациях республики отражена в данных диаграммы 4.

Тувинский язык и литература как предметы изучаются в образовательных организациях республики с 1 по 11 классы, в среднем по 3 часа в неделю (ещё 1 час на их изучение отводится за счет регионального компонента). Данные об изучении тувинского как родного языка по классам обучения и в разрезе по образовательным организациям Кызыла, Ак-Довурака и муниципальных районов / кожуунов в 2018/2019 уч. году, представлены в таблице 3.

Таблица 3. Показатели изучения тувинского как родного языка в общеобразовательных организациях городов и кожуунов РТ в 2018/2019 учебном году, человек.

Table 3. The number of students who studied Tuvan as native language in comprehensive school by city and kozhuun of the Republic of Tuva, 2018/2019.

\begin{tabular}{|c|c|c|c|c|c|c|c|c|c|c|c|c|}
\hline Местонахождение & $\begin{array}{c}1 \\
\text { класс }\end{array}$ & $\begin{array}{c}2 \\
\text { класс }\end{array}$ & $\begin{array}{c}3 \\
\text { класс }\end{array}$ & $\begin{array}{c}4 \\
\text { класс }\end{array}$ & $\begin{array}{c}5 \\
\text { класс }\end{array}$ & $\begin{array}{c}6 \\
\text { класс }\end{array}$ & $\begin{array}{c}7 \\
\text { класс }\end{array}$ & $\begin{array}{c}8 \\
\text { класс }\end{array}$ & $\begin{array}{c}9 \\
\text { класс }\end{array}$ & $\begin{array}{c}10 \\
\text { класс }\end{array}$ & $\begin{array}{c}11 \\
\text { класс }\end{array}$ & $\begin{array}{c}12 \\
\text { класс }\end{array}$ \\
\hline г. Кызыл & 1419 & 1357 & 1400 & 1334 & 1422 & 1004 & 1058 & 1010 & 944 & 165 & 101 & \\
\hline Бии-Хемский & 150 & 119 & 96 & 147 & 116 & 110 & 103 & 97 & 118 & 65 & 49 & 14 \\
\hline Бай-Тайгинский & 211 & 196 & 182 & 225 & 215 & 146 & 148 & 158 & 198 & 115 & 60 & \\
\hline Овюрский & 148 & 130 & 125 & 136 & 114 & 84 & 91 & 104 & 111 & 135 & 30 & \\
\hline Тоджинский & 134 & 109 & 119 & 101 & 99 & 85 & 82 & 94 & 90 & 49 & 49 & \\
\hline Каа-Хемский & 185 & 177 & 175 & 155 & 150 & 109 & 119 & 136 & 133 & 54 & 57 & \\
\hline Чеди-Хольский & 137 & 165 & 135 & 142 & 129 & 98 & 110 & 92 & 107 & 96 & 56 & \\
\hline Тандинский & 225 & 223 & 234 & 225 & 179 & 160 & 123 & 158 & 175 & 87 & 54 & \\
\hline Тере-Хольский & 45 & 37 & 35 & 42 & 43 & 33 & 27 & 31 & 26 & 16 & 19 & \\
\hline Барун-Хемчикский & 275 & 257 & 224 & 236 & 215 & 179 & 171 & 189 & 179 & 90 & 50 & \\
\hline Дзун-Хемчикский & 518 & 490 & 465 & 509 & 487 & 324 & 339 & 321 & 409 & 207 & 111 & \\
\hline $\begin{array}{l}\text { Монгун- } \\
\text { Тайгинский }\end{array}$ & 143 & 123 & 130 & 102 & 107 & 116 & 152 & 97 & 111 & 57 & 32 & \\
\hline Улуг-Хемский & 338 & 353 & 364 & 362 & 345 & 281 & 183 & 302 & 289 & 170 & 108 & 47 \\
\hline Чаа-Хольский & 143 & 141 & 156 & 132 & 144 & 83 & 88 & 86 & 85 & 46 & 14 & \\
\hline
\end{tabular}




\begin{tabular}{|l|c|c|c|c|c|c|c|c|c|c|c|c|}
\hline Тес-Хемский & 211 & 194 & 193 & 214 & 188 & 148 & 150 & 146 & 138 & 75 & 55 & \\
\hline Эрзинский & 143 & 157 & 153 & 165 & 140 & 115 & 129 & 118 & 100 & 69 & 40 & \\
\hline Кызылский & 379 & 414 & 468 & 441 & 431 & 305 & 330 & 375 & 336 & 133 & 87 & 47 \\
\hline Сут-Хольский & 169 & 190 & 169 & 166 & 174 & 122 & 166 & 154 & 167 & 105 & 69 & \\
\hline г. Ак-Довурак & 246 & 249 & 293 & 292 & 279 & 204 & 183 & 199 & 205 & 139 & 83 & \\
\hline \begin{tabular}{l} 
Всего \\
\hline
\end{tabular} & 5219 & 5081 & 5116 & 5126 & 4977 & 3706 & 3752 & 3867 & 3921 & 1873 & 1124 & 108 \\
\hline $\begin{array}{l}\text { Образовательные } \\
\text { респуилации } \\
\text { подчинения }\end{array}$ & 68 & 53 & 81 & 83 & 157 & 191 & 212 & 125 & 113 & 53 & \\
\hline $\begin{array}{l}\text { Итого по } \\
\text { Республике Тыва }\end{array}$ & 5287 & 5134 & 5197 & 5209 & 5134 & 3897 & 3964 & 3992 & 4034 & 1926 & 1124 & 108 \\
\hline
\end{tabular}

Прим.: По данным Института развития национальной школы РТ на конец 2018/2019 уч. года (без учета обучающихся с ограниченными возможностями здоровья).

Большинство детей из семей тувинцев учат родной язык в начальных классах по следующим учебникам:

1 класс - «Үжүглел» («Букварь»),

2-4 классы - учебники «Тыва дыл» («Тувинский язык»),

2-4 классы - учебники «Литературлуг номчулга» («Литературное чтение»).

Учебники с 1 по 4 класс включены в федеральный перечень. Продолжается постоянная работа по обновлению их содержания. В средних и старших классах используются учебники «Тыва дыл» («Тувинский язык») и «Тыва чогаал» («Тувинская литература»), ведется подготовка к включению их в федеральный перечень. Можно также отметить, что для учащихся с русским языком обучения, желающих изучить тувинский язык, отведен 1 час в неделю в ряде общеобразовательных организаций, в т. ч. в СОШ № 1 пгт Каа-Хем (1-3 классы), СОШ № 1 поселка Кызыл-Мажалык, СОШ № 2 г. Туран и некоторых других.

В целом, характеризуя состояние тувинского языка в системе образования последнего десятилетия, можно говорить о том, что в силу несбалансированного языкового регулирования в трансгенерационной передаче тувинского языка очевидны потери.

\section{Учителя тувинского языка и литературы}

Подготовка учителей тувинского языка и литературы и специалистов-филологов по тувинскому языку ведется на филологическом факультете Тувинского государственного университета (на кафедре тувинской филологии и общего языкознания). Направление подготовки - «Педагогическое образование» (44.03.05) с двумя профилями: «Родной язык и литература» и «Иностранный язык». Профилирующие дисциплины изучаются на тувинском языке. В действующих при университете Кызылском педагогическом институте и Кызылском педагогическом колледже выпускают учителей начальных классов, педагогов и воспитателей детских садов, специалистов по коррекционной педагогике и т. д.

В 2018/2019 уч. году тувинский язык и литературу в 1 по 11 классах школ республики преподавали 1407 учителей. Сводные данные учителей начального, среднего и старшего звена по категориям представлены в таблицах 4 и 5.

Как нам удалось выяснить по данным министерства и Института развития национальной школы РТ, доля учителей тувинского языка и литературы с высшей категорией в начальных классах республики составляет $23 \%$, в средних и старших - 36\%, что можно считать удовлетворительным показателем в сравнении с некоторыми другими регионами РФ. На одного учителя тувинского языка и литературы в начальных классах приходится в среднем 19 учеников, в средних и старших классах -79 . Наибольшая нагрузка приходится на учителей городских школ и прежде всего Кызыла (30 учеников на одного 
учителя начальных классов и 154 ученика - на одного учителя средних и старших классов) и школ АкДовурака (соответственно 23 ученика и 129 учеников). В сельских школах кожуунов, часть из которых малокомплектные, на одного учителя тувинского языка и литературы в начальных классах приходится 17 учеников, в то время как в средних и старших классах - свыше 60 учеников.

Таблица 4. Квалификационная характеристика учителей тувинского языка и литературы начальных классов в общеобразовательных организациях РТ в 2018/2019 учебном году, человек.

Table 4. Primary school teachers of Tuvan language and literature by qualification category, at comprehensive schools in the Republic of Tuva, 2018/2019 academic year.

\begin{tabular}{|l|c|c|c|c|}
\hline \multirow{2}{*}{ Местонахождение школ } & \multicolumn{2}{|c|}{ Квалификационная категория учителей } & \multirow{2}{*}{ Всего } \\
\cline { 2 - 4 } & без категории & первая & высшая & 183 \\
\hline г. Кызыл & 37 & 78 & 68 & 46 \\
\hline г. Ак-Довурак & 13 & 13 & 20 & 847 \\
\hline Иные поселения & 223 & 463 & 161 & 1076 \\
\hline Всего & 273 & 554 & 249 & \\
\hline
\end{tabular}

Прим.: Составлено по данным отдела дошкольного, начального общего, основного общего, среднего (полного) общего и специального образования Министерства образования, науки и молодежной политики Республики Тыва ${ }^{1}$ и лаборатории этнокультурного содержания образования Института развития национальной школы РТ.

Таблица 5. Квалификационная характеристика учителей тувинского языка и литературы средних и старших классов в общеобразовательных организациях РТ в 2018/2019 учебном году, человек.

Table 5. Middle and senior school teachers of Tuvan language and literature by qualification category, at comprehensive schools in the Republic of Tuva, 2018/2019 academic year

\begin{tabular}{|l|c|c|c|c|}
\hline \multirow{2}{*}{ Местонахождение школ } & \multicolumn{2}{|c|}{ Квалификационная категория учителей } & \multirow{2}{*}{ Всего } \\
\cline { 2 - 4 } & без категории & первая & высшая & 37 \\
\hline г. Кызыл & 3 & 11 & 23 & 10 \\
\hline г. Ак-Довурак & 2 & 4 & 4 & 284 \\
\hline Иные поселения & 47 & 146 & 91 & 331 \\
\hline Всего & 52 & 161 & 118 & \\
\hline
\end{tabular}

Прим.: Составлено по данным отдела дошкольного, начального общего, основного общего, среднего (полного) общего и специального образования Министерства образования, науки и молодежной политики Республики Тыва и лаборатории этнокультурного содержания образования Института развития национальной школы РТ.

Более серьезная нагрузка на учителей миноритарных языков ощущается в ряде других республик. K примеру, в Кабардино-Балкарии количество учителей балкарского языка и литературы в целом по республике - 182 чел. (из них с высшим образованием 173, со средним - 9). Число изучающих балкарский язык учащихся в 2020-2021 учебном году составляет 15268 (город - 9943 чел., село - 5325 чел.) $)^{2}$. На каждого учителя балкарского языка в среднем приходится более 80 учащихся.

Проблемы в преподавании тувинского языка и литературы связаны с недостатком часов, новыми стандартами, профильным обучением в 9-11 классах, незавершенностью работы по включению в федеральный перечень соответствующих учебников, отсутствием разработанных электронных форм учебников и др. Не вызывает сомнений, что факт перехода с 2018 г. на русскоязычное образование, недостаточное количество учителей тувинского языка и литературы приведет к снижению трансгенерационной функции тувинского языка.

\footnotetext{
${ }^{1}$ Прежние названия министерства и отдела, сегодня это Министерство образования и науки Республики Тыва с измененной структурой.

${ }^{2}$ Информантом выступила д. ф. н., профессор, заведующая кафедрой русского языка и общего языкознания Кабардино-Балкарского государственного университета им. Х. М. Бербекова С. К. Башиева.
} 


\section{Перспективы билингвизма в Туве}

В отличие от других национальных республик России Тува долгое время была, в основном, моноязычной. Тем не менее за почти восемьдесят лет нахождения республики в составе российского государства здесь выросло по крайней мере два поколения тувинцев в новой социокультурной среде. Менявшаяся за этот исторический период языковая ситуация, непоследовательность в реализуемой билингвальной политике Тувы, отчасти связанная с непоследовательностью общей языковой политики в РФ, привели к формированию сложной ситуации коллективного билингвизма, об особенностях которого пишет Н. Ш. Александрова (Александрова, 2018, 2020).

В чем проблематичность этой ситуации? По всей видимости, в системе образования Тувы наметилась тенденция разделения сфер использования тувинского и русского языков. Очевидно, что тувинский не выдерживает конкуренции с русским языком, как и любой другой язык РФ, тем более он фактически с 2018 г. перестал быть языком обучения. А кроме того, раннее введение доминирующего языка в двуязычных учреждениях дошкольного образования также уменьшает сферы использования языка, находящегося в подчиненной позиции.

Несомненно, что такая неравновесная билингвальная ситуация в перспективе может привести к потерям в процессе межпоколенной передачи тувинской культуры, поскольку ее доминирование и устойчивость обусловливались «за счет устойчивого положения тувинского языка, его государственного статуса в республике, широкой сферы использования» (Анайбан, Губогло, Козлов, 1999: 91).

Как правило, замечают ученые, смена языка проходит три стадии. Первой стадии характерно усиление давления на носителей миноритарного языка с целью принудить их к владению мажоритарным языком и в первую очередь, в публичных сферах использования. Процесс этот усиливается при условии введения мажоритарного языка в систему образования, а это «влечет за собой сокращение публичных функций миноритарного языка, (на постсоветском пространстве этот период длился с 1930 по 1990 гг.)» (Богданов, Марусенко М., Марусенко Н., 2020: 158).

Вторая стадия - период билингвизма, когда уменьшается количество молодежи, владеющей этническим языком. Как утверждают ученые, «снижение уровня языковых компетенций и сокращение сфер использования (судя по полемике, вызванной обсуждением проекта изменений “Закона об образовании" Российская Федерация уже прошла эту стадию)» (там же).

На третьей стадии происходит смена миноритарного языка на мажоритарный, который происходит в течение 2-3 поколений. Миноритарным языком владеет небольшое количество людей пожилого возраста, но в качестве коммуникативного средства он практически не используется. «Именно ощущение этой угрозы придало особую остроту дискуссии по проекту изменений “Закона об образовании"» (там же: 159$)$.

Мы солидаризируемся с тувинскими учеными, считающими, что «обучение языку нужно начинать в раннем детстве, так как в более позднем возрасте эффективность процесса снижается. В обучение детей родному языку, передаче им народных обычаев и традиций ведущая роль принадлежит сфере семейного общения, дошкольного воспитания и школьного образования (Серээдар, 2018: 14). Однако упомянутые выше законодательные акты не предусматривали реальное осуществление подобной возможности, что обусловило формирование еще одного поколения тувинцев, у которых этнический язык переходил на периферию языкового сознания.

Свою лепту вносит и ложный тезис о «двух родных языках», инерционно продолжая свое воздействие на понимание билингвального образования как равновесного. Разговоры о преимуществе симметричного / равновесного двуязычия не выдерживают критики в силу невозможности подобного соотношения между двумя языками при коллективном билингвизме (Александрова, 2018: 36-37). «Биофизические процессы, лежащие в основе освоения языков, как и любые другие процессы, неизбежно имеют ограничения. Пластичность мозга настолько искусно обеспечивает наши потребности приобрести новые знания, освоить новый навык, что человеческие возможности кажутся нам порой безграничными. Но на службе пластичности находится инструмент забывания, который стирает то, что меньше используется, стирает старые навыки и знания, чтобы мы могли идти вперед. <...> при естественном билингвизме природой используется особая форма забывания - языковые аттриции ${ }^{1}$ (Александрова, 2020: 175).

${ }^{1}$ Языковая аттриция (языковая эрозия, языковая регрессия, утрата языка, разрушение языка, от англ. language attrition) - процесс разрушения системы родного или хорошо освоенного языка, наблюдаемый у людей, живущих в условиях двуязычия или многоязычия, а также у страдающих разными языковыми патологиями. 
Также как и тувинские ученые, Н. Ш. Александрова, убеждена, что процессу забывания может противостоять одноязычное воспитание дошкольников (если еще есть семьи, где говорят с детьми на этническом языке), а доминирующий язык следует вводить как иностранный логическим путем в школьном возрасте (Александрова, 2018). Кстати говоря, до 2012 г. практика преподавания русского на тувинском языке в ряде сельских школ Тувы - собственно и есть та модель, о которой пишет Н. Ш. Александрова. По ее убеждению, «коллективный билингвизм особенно опасен для языка национального меньшинства, ибо он более подвержен деформации, чем язык национального большинства» (там же: 35-36).

Сужение сфер использования родного языка, не владение им нередко приводит к конфликту между языковой и этнической идентичностью у молодежи (эффект «гадкого утенка» - по Э. Д. Сулейменовой, см.: Сулейменова, 2006). Однако, с другой стороны, желание учащихся расширять свои горизонты, возможности трудовой карьеры диктует задачи овладения языками международного общения русского, английского и др. Этот диалектический процесс языковой реализации новых поколений малочисленных народов - процесс не новый. В истории человечества множество примеров свёртывания коммуникативных мощностей языковых систем, чего не скажешь об их ревитализации (Бахтикиреева, 2020: 16). В этом смысле размышления в пределах лингвистического политкорректного дискурса о невозможности допущения исчезновения языков (Марусенко, 2015: 123), маскируясь за гуманными намерениями, фальсифицируют истинную ситуацию с языками малочисленных народов (Бахтикиреева, 2020: 17).

Равное совершенство двух языков и успешное речевое общение на них в разных сферах их использования невозможно в современных реалиях. Нет сомнений в том, что «языковой вопрос является ключевым в проблеме создания единой гражданской российской нации, формирование которой является условием сохранения национального единства и территориальной целостности Российской Федерации» (Марусенко, 2015: 285). Государственный (русский) язык многонационального общества формирует и поддерживает чувство общенациональной солидарности, рассматривается не просто как часть культуры страны, но как дело политики, экономики, религии. Родной же язык является важнейшим маркером этнической идентичности, символизирующим общность человека с историей, регионом, культурой, традициями предков. Пожалуй, феномен материнского языка для человека удачнее других сформулировал философ М. Мамардашвили: «Ведь материя, о которой я говорю, обладает свойством непрерывности, бесконечности: куда бы мы ни шли, мы не можем отступиться от своего бытия в ней. И куда бы мы ни пришли, мы остаемся внутри этой бесконечности» (Мамардашвили, 1992: 89). Таким образом, вопрос способности тувинского языка отвечать духу информационной эры остается открытым.

Для жизнеспособности тувинского языка необходимо помимо всего прочего последовательное формирование Национального корпуса тувинского языка, о чем пишет М. В. Бавуу-Сюрюн и ее коллеги (Бавуу-Сюрюн, 2016; Дагбажык, 2016; Монгуш, 2016; Ооржак и др., 2016; Ондар, 2016). Любой современный мировой язык, включая русский, имеет свой национальный корпус, по значению для познания языка и его развития их сравнивают с изобретением микро- и телескопа, рентгеновского аппарата, томографа и проч. Открытый весной 2004 г. Национальный корпус русского языка (https:// ruscorpora.ru) стал мощной площадкой для поиска электронного онлайн-корпуса текстов вплоть до церковнославянских, древнерусских, среднерусских. Оформление тувинского языка во всем многообразии дискурсов, развитие и становление его норм, от фонетических до стилистических и других норм требует не только много времени и усилий, подвижничества и солидарности этнической общности, но и республиканской программы с финансированием.

Преодолению существующего положения дел, как представляется, может способствовать Постановление Правительства Республики Тыва № 610 от 08 декабря 2020 г., утвердившее государственную программу Республики «Развитие государственных языков Республики Тыва на 2021-2024 годы». Этим документом 17 предыдущих постановлений, касающихся развития тувинского и русского языка в республике (в частности -упомянутые в настоящей статье), признаны утратившими силу с 1 января 2021 г. ${ }^{1}$

${ }^{1}$ Постановление Правительства Республики Тыва от 08.12.2020 № 610 «Об утверждении государственной программы Республики Тыва “Развитие государственных языков Республики Тыва на 2021-2024 годы”» [Электронный ресурс] // Официальный интернет-портал правовой информации. URL: http://publication.pravo. gov.ru/Document/View/1700202012100001 (дата обращения: 21.01.2021). 
Новая программа рассматривается как основа современной языковой политики в республике и создана с целью: а) развития русского языка как инструмента формирования и укрепления единого образовательного пространства РФ и РТ и б) создания условий для сохранения и развития тувинского языка как государственного языка Республики Тыва ${ }^{1}$.

В этом документе подробно формулируются конкретные задачи, целевые индикаторы и показатели, объемы бюджетных ассигнований, ожидаемые результаты от реализации Программы. Среди важнейших задач обозначены поддержка и сохранение функционирования русского языка с целью консолидации российского общества, создание условий для сохранения тувинского языка как государственного языка Республики Тыва, повышение качества обучения тувинскому языку в системе образования, следование стратегии сохранения и упрочения сбалансированного тувинско-русского и русско-тувинского билингвизма. Обеспечение знания русского языка как государственного и языка межнационального общения всем населением республики будет осуществляться в соответствии со стратегий паритетного статуса и сбалансированного функционирования этих видов билингвизма в республике 2 . Однако, следует отметить, что именно задача сохранения языкового паритета, предполагающего сбалансированное билингвальное образование является одной из самых сложных в смысле реального воплощения.

\section{Заключение}

История преобразований в сфере лингвистического образования в Туве неразрывно связана с разновекторными изменениями национально-языковой политики России. Наряду с судьбоносными для тувинского народа позитивными изменениями неизбежными были и потери и, в частности социокультурной и собственно лингвистической витальности тувинского языка в системе образования. По всей видимости, процесс этот закономерный, если рассматривать это соотношение в масштабах всех миноритарных языков не только в РФ, но и мире.

Новая государственная программа оценивается нами как своевременная, поскольку один из наиболее «стойких» национальных языков РФ - тувинский - претерпевает проблематичный путь своего развития во всех сферах его использования. И его перспективы сегодня зависят от способности отвечать вызовам информационной эры. Тувинские ученые справедливо писали о том, что глобальное развитие цифровых и компьютерных технологий, увеличение молодежного сегмента пользователей сети Интернет обусловливает выделение «нового этапа в фунцциональном развитии миноритарных языков, в частности тувинского языка - функциональное развитие в цифровую эпоху» (Цыбенова, 2018: 63).

Сегодня даже дошкольник может стать блогером, высказывать свое мнение, комментировать, добровольно входить и выходить из виртуального пространства. «Гаджет-поколение» без учителей осваивает новые электронные формы текстов, сочетающие в себе возможности и средства разных семиотических систем. Словом, современные учащиеся нуждаются в учебной литературе нового формата. Учителям, и не только обучающим тувинскому языку, необходима лингвистическая литература по электронным текстам, методические описания этих текстов для дошкольных учреждений, школ, вузов, методики работы с аутентичными и вторичными электронными, по сути, синкретичными текстами. Не менее важно концептуальное переосмысление подготовки учителей, которые в новых условиях взаимодействия с учащимися практически обязаны стать аттрактивной ролевой моделью, способной транслировать знания поколениям новой формации. И все эти вопросы, как и целый комплекс других мер предписаны в новой государственной программе. Последовательное осуществление всех намеченных в новой программе тактических шагов, как представляется, во многом определят перспективы билингвального образования Республики Тыва.

\section{Благодарности}

Авторы благодарят Светлану Владимировну Монгуш, начальника отдела общего образования Министерства образования и науки Республики Тыва и Тамару Буурекчиировну Оюн, заведующую лабораторией этнокультурного содержания образования Института развития национальной школы Республики Тыва за предоставленные статистические данные и материалы по теме статьи.

\footnotetext{
${ }^{1}$ Постановление Правительства Республики Тыва от 08.12.2020 № 610 ... С. 2.

2 Там же. С. 7-8.
} 


\section{СПИСОК ЛИТЕРАТУРЫ}

Александрова, Н. Ш. (2018) Исчезновение языков, естественный билингвизм и нелинейная динамика // Восьмая международная конференция по когнитивной науке: Тезисы докладов. Светлогорск, 18-21 октября 2018 г. / отв. ред. А. К. Крылов, В. Д. Соловьев. М.: Изд-во «Институт психологии РАН». 1368 с. С. $35-37$.

Александрова, Н. Ш. (2020) Билингвизм и другие проявления функционирования языковой системы в свете пластичности мозга // Филологические науки. Научные доклады высшей школы. № 6 (2). С. 170-176.

Анайбан, 3. В., Губогло, М. Н., Козлов, М. С. (1999) Формирование этнополитической ситуации. Т. 1. Очерки по истории постсоветской Тувы. М. : ЦИМО. 420 с.

Арефьев, А. Л. (2018) Социология языка. Национальные и иностранные языки в системе образования. 2-е изд., перераб. и доп. М. : Юрайт. 311 с.

Бахтикиреева, У. М. (2020) Изучение и описание национальных образов коренных народов РФ посредством носителей языка, фольклора и литературы - осознанная необходимость // Сохранение и развитие языков и культур коренных народов Сибири: материалы IV Всероссийской научно-практической конференции (Абакан, 1-2 октября 2020 г.) / отв. ред. Т.Г. Боргоякова. Абакан : Издательство ФГБОУ ВО «Хакасский государственный университет им. Н. Ф. Катанова. 232 с. С. 14-22.

Беликов, В. И., Крысин, Л. П. (2001) Социолингвистика : учебник для вузов. М. : Рос. гос. гуманит. ун-т. 317 с.

Боргоякова, Т. Г., Биткеева, А. Н. (2020) Тувинский язык в правовом и функциональном измерении // Новые исследования Тувы. № 1. С. 50-59. DOI: 10.25178/nit.2020.1.4

Бавуу-Сюрюн, М. В. (2010) Тувинский язык на современном этапе: образовательный аспект [Электронный ресурс] // Новые исследования Тувы. № 3. С. 57-71. URL: https://nit.tuva.asia/nit/article/view/500 (дата обращения: 20.01.2021).

Бавуу-Сюрюн, М. В. (2016) Вопросы создания электронных ресурсов тувинского языка: некоторые итоги, неотложные задачи и перспективы [Электронный ресурс] // Новые исследования Тувы. № 4. C. 4-27. URL: https://nit. tuva.asia/nit/article/view/610 (дата обращения: 20.01.2021).

Богданов, С. И., Марусенко, М. А., Марусенко, Н. М. (2020) Языковые переписи и мониторинги как инструмент национальной языковой политики. СПб. : Изд-во РГПУ им. А. И. Герцена. 344 с.

Дагбажык, А. С. (2016) Структура словарной статьи Национального корпуса тувинского языка [Электронный ресурс] // Новые исследования Тувы. № 4. С. 36-44. URL: https://nit.tuva.asia/nit/article/view/612 (дата обращения: 20.01.2021).

Донгак, Ч. Б. (2020) Языковая политика и проблема контактного билингвизма в национальных республиках России (на примерах республик Татарстан, Тыва и Саха (Якутия) // Вестник Тувинского государственного университета. Выпуск 1. Социальные и гуманитарные науки, № 4 (68). С. 63-72.

Мамардашвили, М. К. (1992) Законы инакомыслия // Здесь и теперь. № 1. С. 85-93.

Марусенко, М. А. (2015) Языки и национальная идентичность: современные вызовы национальному единству и территориальной целостности. М. : Научно-политическая книга. 575 с.

Монгуш, Ч. М. (2016) Метатекстовая разметка в Национальном корпусе тувинского языка: структура и функциональные возможности [Электронный ресурс] // Новые исследования Тувы. № 4. C. 45-52. URL: https://nit.tuva. asia/nit/article/view/613 (дата обращения: 20.01.2021).

Сат, Ш. Ч. (1973) Формирование и развитие тувинского национального литературного языка. Кызыл : Тувинское книжное издательство. 193 с.

Товуу, С. С., Кара-Сал, Н. М., Санчаа, Т. О. (2020) Математическое образование в условиях развития системы образования Тувы // Новые исследования Тувы. № 4. C. 45-63. DOI: www.doi.org/10.25178/nit.2020.4.4

Ондар, М. В. (2016) База данных текстов тувинского героического эпоса: первый этап [Электронный ресурс] // Новые исследования Тувы. № 4. C. 66-76. URL: https://nit.tuva.asia/nit/article/view/616 (дата обращения: 20.01.2021).

Ооржак, Б. Ч., Хертек, А. Б., Кужугет, М. А., Ондар, В. С. (2016) Семантическая разметка имени для Электронного корпуса текстов тувинского языка [Электронный ресурс] // Новые исследования Тувы. № 4. C. 53-65. URL: https:// nit.tuva.asia/nit/article/view/615 (дата обращения: 20.01.2021).

Очур, Н. М. (2015) Развитие двуязычия в школах Тувы в постсоветский период // Вестник ТПгУ. № 4 (157). C. 93-97.

Серээдар, Н. Ч. (2018) Тувинский язык как средство общения тувинцев: проблемы и перспективы // Новые исследования Тувы. № 1. С. 4-19. DOI: https://www.doi.org/10.25178/nit.2018.1.1 
Сулейменова, Э. Д. (2006) Архетип «гадкого утенка» и языковая идентичность // «Язык и идентичность», международная научно-теоретическая конференция (2006; Алма-Ата) : сборник материалов Международной научно-теоретической конференции «Язык и идентичность», Ахановские чтения, 12-13 мая = «Тіл және сәйкестік» Халықаралық ғылыми-теориялық конференциясының материалдардың жинағы, К. Аханов тағылымы, 12-13 мамыр = Collected articles of International scientific-theoretical conference "Language and identity", Akhanov conference, 12-13 Мау / редкол.: Н. Ж. Шаймерденова и др. Алматы : Қазақ университеті. 361 с. С. 15-26.

Цыбенова, Ч. С. (2013) Современная языковая ситуация в Республике Тыва : автореф. дисс. ... канд. филол. н. М. $24 \mathrm{c}$.

Цыбенова, Ч. С. (2018) Функциональное развитие тувинского языка: диахронический аспект // Томский журнал ЛИНГ и АНТР. № 3 (21). С. 56-66.

Цыбенова, Ч. С. (2019) Социальная характеристика языковой ситуации в Республике Тыва // Oriental Studies. № 3. C. 460-477. DOI: https://doi.org/10.22162/2619-0990-2019-43-3-460-477

Дата поступления: 01.02.2021 2.

\section{REFERENCES}

Aleksandrova, N. Sh. (2018) Ischeznovenie iazykov, estestvennyi bilingvizm i nelineinaia dinamika [The disappearance of languages, natural bilingualism, and nonlinear dynamics]. In: Vos'maia mezhdunarodnaia konferentsiia po kognitivnoi nauke [Eighth International Conference on Cognitive Science]: Abstracts of reports. Svetlogorsk, October 18-21, 2018 / ed. by A. K. Krylov and V. D. Solov'ev. Moscow, Institut psikhologii RAN Publ. 1368 p. Pp. 35-37. (In Russ.).

Aleksandrova, N. Sh. (2020) Bilingvizm i drugie proiavleniia funktsionirovaniia iazykovoi sistemy v svete plastichnosti mozga [Bilingualism and other manifestations of the functioning of the language system in light of brain plasticity]. Philological sciences. Scientific essays of higher education, no. 6 (2), pp. 170-176. (In Russ.).

Aref'ev, A. L. (2018) Sotsiologiia iazyka. Natsional'nye i inostrannye iazyki v sisteme obrazovaniia [Sociology of language. National and foreign languages in the education system]. $2^{\text {nd }}$ ed. Moscow, Yurait. 311 p. (In Russ.).

Bakhtikireeva, U. M. (2020) Izuchenie i opisanie natsional'nykh obrazov korennykh narodov RF posredstvom nositeleǐ iazyka, fol'klora i literatury - osoznannaia neobkhodimost' [Studying and describing national images of the indigenous peoples of the Russian Federation through the eyes of native speakers of language, folklore and literature: A conscious need]. In: Sokhranenie i razvitie iazykov i kul'tur korennykh narodov Sibiri [Preserving and developing languages and cultures of the indigenous peoples of Siberia]: proceedings of the $4^{\text {th }}$ All-Russian Research Conference (Abakan, October 1-2, 2020) / ed. by T.G. Borgoiakova. Abakan, Izdatel'stvo FGBOU VO «KhakasskiǏ gosudarstvennyǐ universitet im. N. F. Katanova. 232 p. Pp. 14-22. (In Russ.).

Belikov, V. I. and Krysin, L. P. (2001) Sotsiolingvistika [Sociolinguistics]: a textbook for universities. Moscow, Ros. gos. gumanit. un-t. 317 p. (In Russ.).

Borgoiakova, T. G. and Bitkeeva, A. N. (2020) Tuvinskii iazyk v pravovom i funktsional'nom izmerenii [Tuvan language in legal and functional aspect]. New Research of Tuva, no. 1, pp. 50-59. (In Russ.). DOI: https://doi.org/10.25178/nit.2020.1.4

Bavuu-Surun, M. V. (2010) Tuvinskii iazyk na sovremennom etape: obrazovatel'nyi aspekt [Tuvan language on modern stage: educational aspect]. New Research of Tuva, no. 3, pp. 57-71 [online] Available at: https://nit.tuva.asia/nit/article/ view/500 (access date: 20.01.2021). (In Russ.).

Bavuu-Surun, M. V. (2016) Voprosy sozdaniia elektronnykh resursov tuvinskogo iazyka: nekotorye itogi, neotlozhnye zadachi i perspektivy [Creating electronic resources on Tuvan language: preliminary results, current challenges and prospects]. New Research of Tuva, no. 4, pp. 4-27 [online] Available at: https://nit.tuva.asia/nit/article/view/610 (access date: 20.01.2021). (In Russ.).

Bogdanov, S. I., Marusenko, M. A. and Marusenko, N. M. (2020) Iazykovye perepisi i monitoringi kak instrument natsional'noi iazykovoi politiki [Language census and monitoring as an instrument of national language policy]. St. Petersburg, Izdvo RGPU im. A. I. Gertsena. 344 p. (In Russ.).

Dagbazhyk, A. S. (2016) Struktura slovarnoi stat'i Natsional'nogo korpusa tuvinskogo iazyka [The structure of an entry in the National corpus of Tuvan language]. New Research of Tuva, no. 4, pp. 36-44 [online] Available at: https://nit.tuva. asia/nit/article/view/612 (access date: 20.01.2021). (In Russ.).

Dongak, Ch. B. (2020) Iazykovaia politika i problema kontaktnogo bilingvizma v natsional'nykh respublikakh Rossii (na primerakh respublik Tatarstan, Tyva i Sakha (Yakutila) [Language policy and the problem of contact bilingualism in the national Republics of Russia: the cases of the Republics of Tatarstan, Tuva and Sakha (Yakutia)]. Vestnik Tuvinskogo gosudarstvennogo universiteta. Issue 1. Sotsial'nye i gumanitarnye nauki, no. 4 (68), pp. 63-72. (In Russ.). 
Mamardashvili, M. K. (1992) Zakony inakomysliia [The laws of dissent]. Zdes' i teper', no. 1, pp. 85-93. (In Russ.).

Marusenko, M. A. (2015) Iazyki i natsional'naia identichnost': sovremennye vyzovy natsional'nomu edinstvu i territorial'noi tselostnosti [Languages and National identity: Modern Challenges to National Unity and Territorial Integrity]. Moscow, Nauchno-politicheskaia kniga. 575 p. (In Russ.).

Mongush, Ch. M. (2016) Metatekstovaia razmetka v Natsional'nom korpuse tuvinskogo iazyka: struktura i funktsional'nye vozmozhnosti [A metatextual markup in the national corpus of Tuvan language: the structure and functionality]. New Research of Tuva, no. 4, pp. 45-52 [online] Available at: https://nit.tuva.asia/nit/article/view/613 (access date: 20.01.2021). (In Russ.).

Sat, Sh. Ch. (1973) Formirovanie i razvitie tuvinskogo natsional'nogo literaturnogo iazyka [The Formation and development of the Tuvan literary language]. Kyzyl, Tuvan book publisher. 193 p. (In Russ.).

Tovuu, S. S., Kara-Sal, N. M. and Sanchaa, T. O. (2020) Matematicheskoe obrazovanie v usloviiakh razvitiia sistemy obrazovaniia v Respublike Tyva [Mathematical education in the development of the educational system in the Republic of Tuva]. New Research of Tuva, no. 4, pp. 45-63. (In Russ.). DOI: www.doi.org/10.25178/nit.2020.4.4

Ondar, M. V. (2016) Baza dannykh tekstov tuvinskogo geroicheskogo eposa: pervyi etap [The structure of an entry in the National corpus of Tuvan language]. New Research of Tuva, no. 4, pp. 66-76 [online] Available at: https://nit.tuva.asia/ nit/article/view/616 (access date: 20.01.2021). (In Russ.).

Oorzhak, B. Ch., Khertek, A. B., Kuzhuget, M. A. and Ondar, V. S. (2016) Semanticheskaia razmetka imeni dlia Elektronnogo korpusa tekstov tuvinskogo iazyka [Semantic markup of nouns and adjectives for the Electronic corpus of texts in Tuvan language]. New Research of Tuva, no. 4, pp. 53-65 [online] Available at: https://nit.tuva.asia/nit/article/view/615 (access date: 20.01.2021). (In Russ.).

Ochur, N. M. (2015) Razvitie dvuiazychiia v shkolakh Tuvy v postsovetskii period [The development of bilingualism in schools of Tuva in Post-soviet period]. TSPU Bulletin, no. 4 (157), pp. 93-97. (In Russ.).

Sereedar, N. Ch. (2018) Tuvinskii iazyk kak sredstvo obshcheniia tuvintsev: problemy i perspektivy [Tuvan language as a means of communication among Tuvans: Problems and prospects]. New Research of Tuva, no. 1, pp. 4-19. (In Russ.). DOI: https://www.doi.org/10.25178/nit.2018.1.1

Suleimenova, E. D. (2006) Arkhetip «gadkogo utenka» i iazykovaia identichnost' [The archetype of the "ugly duckling” and language identity]. In: Proceedings of International research conference "Language and identity”, (Akhanov Readings), 12-13 May / ed. by N.Zh. Shaimerdenova et al. Almaty, Қаzaқ universiteti. 361 p. Pp. 15-26. (In Russ.).

Tsybenova, Ch. S. (2013) Sovremennaia iazykovaia situatsiia v Respublike Tyva : sotsiopsikholingvisticheskii aspekt [The Contemporary Linguistic Situation in the Republic of Tyva: The Socio- and Psycholinguistic aspect] : Abstract of Diss. ... Candidate of Philology. Ulan-Ude. 24 p. (In Russ.).

Tsybenova, Ch. S. (2018) Funktsional'noe razvitie tuvinskogo iazyka: diakhronicheskii aspekt [Functional development of the Tuva language: the diachronic aspect]. Tomsk Journal LING \& ANTHRO, no. 3 (21), pp. 56-66. (In Russ.).

Tsybenova, Ch. S. (2019) Sotsial'naia kharakteristika iazykovoi situatsii v Respublike Tyva [Language Situation in the Republic of Tuva: Social Characteristics.]. Oriental Studies, no. 3, pp. 460-477. (In Russ.). DOI: https://doi. org/10.22162/2619-0990-2019-43-3-460-477

Submission date: 01.02.2021. 